\author{
dr inż. Pawel Bartoszczuk \\ Szkoła Główna Handlowa w Warszawie \\ Instytut Przedsiębiorstwa \\ e-mail: pbarto1@sgh.waw.pl
}

\title{
EKOINNOWACJE W GOSPODARCE WODNEJ ${ }^{1}$
}

\author{
ECO-INNOVATION IN WATER ECONOMY
}

\begin{abstract}
The article discusses the definition, classification and barriers of eco-innovation in water sector. This concept is difficult to define and still under discussion how the definition of innovation can be applied to eco-innovation. The effect of ecoinnovation is not only improving the environment, but at the same time reducing the costs in the enterprise, eg. reduction of penalties or fees for pollution. Based on data from Gallup foundation the impact of various factors on the introduction of of product, process and organizational eco-innovation was analysed.
\end{abstract}

Keywords: enterprise, organisational ecoinnovation, product ecoinnovation, process ecoinnovation, enterprise

JEL classification: O30, Q53, Q55

\section{Wstęp}

Problem badawczy dotyczący ekoinnowacji w gospodarce, a szczególnie w gospodarce wodnej nie jest dotychczas wystarczająco dobrze rozpoznany. Badania dotyczące działalności ekoinnowacyjnej przedsiębiorstw w Polsce są podejmowane stosunkowo rzadko. Wybrane aspekty specyfiki takiej działalności były dotychczas przedmiotem analiz przeprowadzonych m.in. przez Główny Urząd Statystyczny, PSDB we współpracy z GfK Polonia na zlecenie PARP, Fundację Partnerstwo dla Środowiska, a także Instytut Gallupa w ramach badania Eurobarometru. Nazwa „ekoinnowacje” pojawiła się pod koniec lat 90. XX w. i jest pojęciem bardzo trudnym do zdefiniowania, podobnie jak innowacje, i wciąż nie ma ścisłych kryteriów

${ }^{1}$ Projekt został sfinansowany ze środków Narodowego Centrum Nauki przyznanych na podstawie decyzji numer DEC-2013/11/B/HS4/02122. 
ani teorii wyjaśniających jej istotę. Obecnie tocząca się debata w literaturze światowej² dotyczy problemu, w jakim stopniu ekoinnowacje są jedną z form działalności innowacyjnej, która potrzebuje własnej teorii i zupełnie innego podejścia ${ }^{3}$. Stwierdza się jedynie, że teoria innowacji ekologicznych może korzystać z ogólnej teorii innowacji, jednak ogólna teoria innowacji nie wyjaśnia stopnia złożonego charakteru ekoinnowacji oraz czynników im sprzyjających ${ }^{4}$. W związku z tym szeroko dyskutuje się, czy jest uprawnione przeniesienie istniejących teorii innowacji do innowacji ekologicznych ${ }^{5}$, a bardziej szczegółowo - czy bariery dla firm wprowadzających ekoinnowacje są takie same jak dla firm wprowadzających ogólne innowacje. Innowacje zmieniające istniejący stan są przedmiotem zainteresowania dyscyplin naukowych od nauk technicznych poprzez ekonomiczne, społeczne aż do nauk o zarządzaniu. W niniejszej pracy podjęto próbę zbadania istotności poszczególnych barier wprowadzania ekoinnowacji w przedsiębiorstwach.

Pomiar zużycia wody i ekoinnowacyjnych praktyk opartych na redukcji zużywanej wody jest rekomendowany przez ekonomistów jako istotny składnik skutecznej gospodarki wodnej. Harutyunyan analizuje proces wprowadzenia opomiarowania dla miejskiej sieci wodociągowej w Armenii ${ }^{6}$. Głównym celem jest analiza przejścia do systemu opartego na pomiarze wody, przy skoncentrowaniu się na związanych z tym przekształceniach w zarządzaniu wodą i skutkach opomiarowania zużycia wody dla odbiorców w gospodarstwach domowych i wpływie na funkcjonowanie przedsiębiorstw wodnych. Autorka zwraca uwagę, że w ciągu krótkiego okresu poziom opomiarowania zużycia wody przez mieszkańców Armenii osiągnął prawie 99\%. Pomiar poziomu zużycia w indywidualnym mieszkaniu, a nie w całym budynku sprzyja oszczędnościom. Pomiar poprawia niezawodność dostaw wody i zwiększa efektywność jej wykorzystania. Efekty oszczędzania opomiarowanego zużycia wody były wyższe w początkowym okresie po instalacji liczników i w okresie 2009-2010, w którym wzrosły taryfy opłat za wodę. W krótkim okresie zaobserwowano czterokrotny spadek zużycia wody w lokalach mieszkalnych. Jednak obniżki rachunków za wodę zobserwowane w gospodarstwach domowych i brak wzrostu cen spowodowały ponowny wzrost konsumpcji - aż o 70\%. W dłuższej perspektywie opomiarowaniu towarzyszyła wynosząca 48\% redukcja zapotrzebowania na wodę w mieszkaniach, nawet w świetle poprawy usług zaopatrzenia w wodę. Wreszcie, kwestią kluczową w zapobieganiu stratom wody jest wymiana liczników.

2 S. Jakobsen, T. Clausen, Comparing the innovation process in environmental and non-environmental firms: A look at barriers to innovation. DRUID Society Conference, CBS, Copenhagen 2014.

3 V. De Marchi, Environmental innovation and $R \& D$ cooperation: Empirical evidence from Spanish manufacturing firms, ,Research Policy” 2012, vol. 41, no. 3.

4 Tamże.

${ }^{5} \mathrm{~K}$. Rennings, Redefining innovation - eco-innovation research and the contribution from ecological economics, „Ecological Economics” 2000, vol. 32.

${ }^{6} \mathrm{~N}$. Harutyunyan, Metering drinking water in Armenia: The process and impacts, ,Journal of Sustainable Cities and Society" 2014, vol. 14. 
Abdala $^{7}$ badał czy użytkownicy reagują na taryfy progresywne, i wykazali, że grupy o najniższych dochodach rzeczywiście reagują na zmiany w cenie wody, szczególnie na taryfy blokowe.

\section{Metody badawcze}

W pracy zostały zastosowane różne metody badawcze, to znaczy pogłębiona analiza literatury oraz metoda wywiadu. Na początku dokonano przeglądu definicji terminu „ekoinnowacje”. Istnieje bardzo wiele definicji innowacji, jak również ekoinnowacji. Fussler stwierdził, że ,eko-innowacje to proces opracowywania nowych produktów, procesów lub usług, które zapewniają konsumentom i biznesowi wartość, a jednocześnie zmniejszają oddziaływanie na środowisko"8. Podział innowacji w zależności od przyjętych kryteriów został przedstawiony w tabeli 1.

Tabela 1. Podzial innowacji według wybranych kryteriów

\begin{tabular}{|l|l|l|}
\hline \multicolumn{1}{|c|}{ Kryterium } & Rodzaj innowacji & \multicolumn{1}{c|}{ Opis } \\
\hline \multirow{2}{*}{ obiekt } & produktowe & nowy produkt, produkt zmodernizowany \\
\cline { 2 - 3 } & technologiczne & $\begin{array}{l}\text { całkowita lub częściowa zmiana czynników lub } \\
\text { właściwości procesów wytwórczych i proporcji } \\
\text { między nimi }\end{array}$ \\
\cline { 2 - 3 } & organizacyjne & lean management, kaizen, zarządzanie jakością \\
\cline { 2 - 3 } & społeczne & $\begin{array}{l}\text { zmiana systemów motywacyjnych, kultury } \\
\text { organizacyjnej }\end{array}$ \\
\cline { 2 - 3 } $\begin{array}{l}\text { stosunek do śro- } \\
\text { dowiska przyrod- } \\
\text { niczego }\end{array}$ & $\begin{array}{l}\text { marketingowe } \\
\text { (ekoinnowacje) }\end{array}$ & $\begin{array}{l}\text { zmiana koncepcji i technik marketingowych } \\
\text { prowadzą do oszczędności zużycia materiałów; } \\
\text { nych }\end{array}$ \\
\cline { 2 - 3 } & obojętne & $\begin{array}{l}\text { obojętne dla środowiska przyrodniczego } \\
\text { i człowieka }\end{array}$ \\
\cline { 2 - 3 } & $\begin{array}{l}\text { naruszające } \\
\text { równowagę } \\
\text { ekologiczną }\end{array}$ & $\begin{array}{l}\text { powodują negatywny wpływ na elementy } \\
\text { środowiska przyrodniczego i człowieka }\end{array}$ \\
\hline
\end{tabular}

Źródło: opracowanie własne na podstawie: L. Białoń, Zarzadzanie działalnościa innowacyjna, Placet, Warszawa 2010, s. 21-24.

7 M.A. Abdala, Governance of competitive transmission investment in weak institutional systems, „Energy Econ” 2008, vol. 30, no. 4, s. 1306-1320.

${ }^{8}$ C. Fussler, P. James, Driving eco-innovation: A breakthrough discipline for innovation and sustainability, Pitman Publishing, London 1996. 
Szczególną uwagę zwracamy na kryterium: stosunek do środowiska przyrodniczego, zgodnie z którym można wyodrębnić ekoinnowacje 9 .

Ekoinnowacje należy rozpatrywać przynajmniej z trzech perspektyw:

- poszczególnych organizacji i przedsiębiorstw sfery produkcyjnej, a także sfery usług;

- układów przestrzennych (gmin, miast, województw, regionów różnej wielkości, aż po skalę globalną);

- konsumentów (indywidualnych i instytucjonalnych).

Powszechnie uznaje się, że ekoinnowacje zmierzają do rozwoju nowych produktów i procesów, które nie tylko dostarczają konsumentowi i biznesowi korzyści, ale istotnie zmniejszają oddziaływanie środowiskowe ${ }^{10}$. Fussler i James ${ }^{11}$ definiują ekoinnowacje jako nowe produkty i procesy, które dostarczają biznesowi i klientom wartości ze znacznym zmniejszeniem oddziaływania na środowisko.

Ekoinnowacją może być produkt ekologiczny czy proces technologiczny, który podlega dalszej klasyfikacji. Ekoinnowacja technologiczna to wdrożenie do powszechnego wykorzystania nowych produktów, technologii oraz urządzeń infrastruktury, których celem jest ochrona elementów środowiska: powietrza, wód, ziemi, krajobrazu, flory i fauny, a także człowieka przed negatywnym wpływem działalności gospodarczej. W efekcie wdrożenie ekoinnowacji powinno prowadzić do zrównoważonego rozwoju.

Interesujące rozróżnienie ekoinnowacji i tradycyjnych innowacji zaproponowali R. Kemp i P. Pearson ${ }^{12}$. Otóż doszli oni do przekonania, że aby określić, czy innowacje mają charakter ekologiczny, należy wykazać, że w wyniku ich zastosowania negatywny wpływ na środowisko zmniejsza się w stosunku do efektów

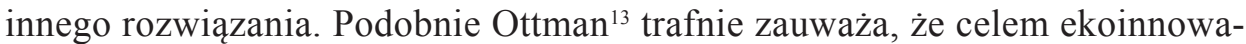
cji jest redukcja negatywnego oddziaływania przedsiębiorstwa na środowisko przyrodnicze.

Część problemów wynika z względnego charakteru definicji innowacji. Przykładowo, użycie urządzeń kontroli zanieczyszczeń przez przedsiębiorstwo jest innowacją z punktu widzenia konkretnego przedsiębiorstwa, ale nie będzie już innowacją dla producenta tego urządzenia.. Kiedy mierzymy ekoinnowacje, należy

9 W. Janasz, Innowacje i ich miejsce w tworzeniu wartości przedsiębiorstwa, [w:] Innowacje $w$ działalności przedsiębiorstw w integracji z UE, Difin, Warszawa 2005, s. 40.

${ }^{10}$ B. Ziółkowski' Znaczenie ekoinnowacji dla rozwoju przedsiębiorstw, [w:] A. Graczyk (red.), Zrównoważony rozwój w teorii ekonomii i w praktyce, Wydawnictwo Akademii Ekonomicznej we Wrocławiu, Wrocław 2007, s. 526-534, Prace Naukowe AE, nr 1190.

${ }^{11}$ C. Fussler, T. James, Driving eco-innovation...

${ }_{12}$ R. Kemp, P. Pearson, Measuring eco-innovation. Final report of MEI project for DG Research of the European Commission, MEI, Brussels 2007.

${ }_{13}$ J. Ottman, The New Rules of Green Marketing: Strategies, Tools and Inspiration for Sustainable Branding, Greenleaf Publishing, Sheffield 2011. 
wyjaśnić, czy mamy na myśli pomiar tworzenia innowacji lub pierwsze wdrożenie produktów, technologii, usług lub praktyk. Inne ważne rozróżnienie to takie, czy dana innowacja powoduje poprawę, w przypadku gdy dany produkt już istnieje, czy jest to całkowicie nowy produkt.

Nowym terminem jest pojęcie „zrównoważone innowacje”, czyli nowe lub zmodyfikowane procesy, techniki, praktyki, systemy i produkty pozytywnie oddziałujące na środowisko, gospodarkę i społeczeństwo ${ }^{14}$. Pewnym problemem może być stosowanie różnej terminologii, ponieważ oprócz ekoinnowacji stosowane są też inne nazwy: „zielone technologie”, ,technologie środowiskowe”, „technologie ekologiczne”, ,ekotechnologie”, „,innowacje ekologiczne” i inne ${ }^{15}$.

Ekoinnowacje nazywane także zielonymi lub innowacjami środowiskowymi, stanowią szerokie pojęcie, które uwzględnia również „niezaplanowane innowacje ekologiczne"16. Podsumowując, definicje innowacji środowiskowych uwzględniają cztery różne rodzaje innowacji: zrównoważone, ekologiczne, środowiska i zielone oraz pokazują drobne różnice $\mathrm{w}$ ich opisie. $\mathrm{W}$ odniesieniu do zawartości pokazują te same kwestie i mogą być stosowane zamiennie.

Szeroko dyskutowana jest kwestia, na jakie bariery natrafiają firmy wprowadzające ekoinnowacje, a na jakie firmy wprowadzających tylko ogólne innowacje.

Poza pozytywnymi efektami zewnętrznymi generowanymi dzięki dyfuzji innowacji i rozprzestrzenianiu się wiedzy, innowatorzy nie odnoszą pełnych korzyści z redukcji negatywnego oddziaływania na środowisko lub efektywniejszego wykorzystania zasobów naturalnych. Odbiorcom ekoinnowacji trudno jest zawczasu ocenić korzyści środowiskowe z powodu niższych kompetencji w tym obszarze. Nowe rozwiązania środowiskowe wymagają więc potwierdzenia ich skuteczności i spełniania wymagań przedsiębiorstwa. Firmy nie zawsze dostrzegają szanse płynące z wprowadzania rozwiązań proekologicznych (np. w postaci oszczędności wynikających z poprawy efektywności wykorzystania zasobów, wejścia na nowe rynki czy zmniejszenia ryzyka nadzwyczajnych strat).

Problem dotyczący ekoinnowacji w gospodarce wodnej jest zdecydowanie aktualny, istotny dla polskich przedsiębiorstw, polskiej gospodarki. Badania i wprowadzanie innowacji to priorytety w unijnej agendzie na rzecz wzrostu gospodarczego i zatrudnienia. W porównaniu z państwami liderami pod względem wdrażania ekoinnowacji doświadczenia krajowych podmiotów gospodarczych nie były do tej pory w sposób wyczerpujący analizowane i opisane w literaturze. Niektórzy autorzy podkreślają, że realizowany dotąd model wzrostu gospodarczego

${ }^{14}$ F. Steward, Opponent note: ecoinnovation-enviromental benefits [w:] Economic growth and job creation, 2006, s. 3.

15 B. Ziółkowski, Znaczenie ekoinnowacji..., s. 527.

${ }^{16}$ A. Arundel, R. Kemp, Measuring eco-innovation, United Nations University - Maastricht Economic and Social Research and Training Centre on Innovation and Technology, UNU-MERIT Working Papers, UNU, Maastricht 2009. 
Polski dobiegł końca ${ }^{17}$. Nowy model powinien uwzględnić konkurowanie w zakresie wprowadzania ekoinnowacji.

Ważną inicjatywą unijną poświęconą badaniom nad ekoinnowacjami jest obecnie Obserwatorium Ekoinnowacji ${ }^{18}$. Na podstawie wybranych 16 wskaźników został stworzony ranking Eco-innovation, w którym Polska wśród wszystkich członków UE 27 została zaliczona do krajów nadrabiających zaległości.

Niestety, ekoinnowacje pozostają poza orbitą zainteresowań polityków nie tylko w Polsce. W konsekwencji polska polityka kładzie nacisk na likwidację opóźnień cywilizacyjnych, zapominając o przyszłych zmianach znaczenia sektorów gospodarki oraz barierach starego modelu wzrostu opartego na konkurowaniu ceną ${ }^{19}$. Ekoinnowacje wpływają na efektywność gospodarki poprzez wprowadzanie rozwiązań umożliwiających ograniczanie energochłonności procesów i rozwiązań redukujących zużycie materiałów na jednostkę produktu.

\section{Wyniki badania empirycznego}

W badaniu ankietowym zapytano przedsiębiorstwa w Polsce o wprowadzone przez nie sposoby mające doprowadzić do zmniejszenia zużycia wody. Respondenci wskazywali na bardzo konkretne rozwiązania, np. zamykanie obiegów wodnych, zawarte w kafeterii odpowiedzi.

Najczęściej wśród zastosowanych rozwiązań mających przyczynić się do zmniejszenia zużycia wody wymieniano wprowadzenie wodooszczędnych urządzeń, np. bezdotykowych baterii (55\%). Na dalszych miejscach znalazły się: zamykanie obiegów wodnych w zakładach produkcyjnych (27\%), stosowanie wodooszczędnych technologii (22\%), a ponadto recyrkulacja ścieków szarych (13\%).

Do innych wymienionych przez przedsiębiorstwa działań (30\%) należały:

- modernizacja sieci wodociągowej i stacji uzdatniania wody,

- separator substancji tłuszczowych i ropopochodnych z wody deszczowej niepodlegającej odzyskowi z dróg,

- odwodnienie kamieniołomów, wyrobisk - wody kopalniane, opadowe (wodę wykorzystuje się do celów przemysłowych, chłodniczych),

- krany czasowe,

- recyrkulacja wody.

${ }_{17}$ M. Bukowski, A. Szpor, A. Śniegocki, Drzemiacy tygrys, spętany orzet: Dylematy polskiej debaty o polityce innowacyjnej, Instytut Badań Strukturalnych, Warszawa 2012.

${ }^{18}$ Ecoinnovation Observatory, www.eco-innovation.eu/ (dostęp: 15.07.2016).

19 M. Bukowski, A. Szpor, A. Śniegocki, Drzemiacy tygrys ...; A. Kassenberg, A. Śniegocki, Rola (eko)innowacji w niskoemisyjnej transformacji, Instytut na Rzecz Ekorozwoju, Warszawa 2011. 


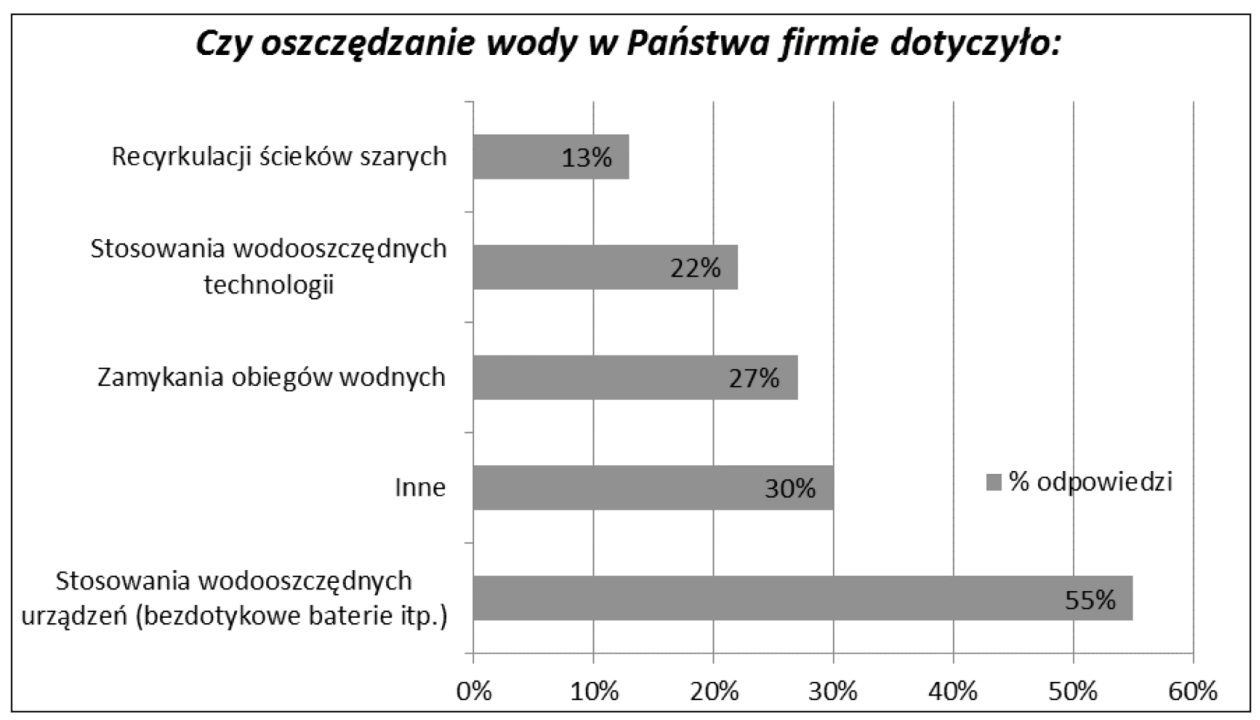

Rysunek 1. Działania podjęte w badanych przedsiębiorstwach zmierzające w kierunku zmniejszenia zużycia wody

Źródło: opracowanie własne na podstawie wyników badań ankietowych.

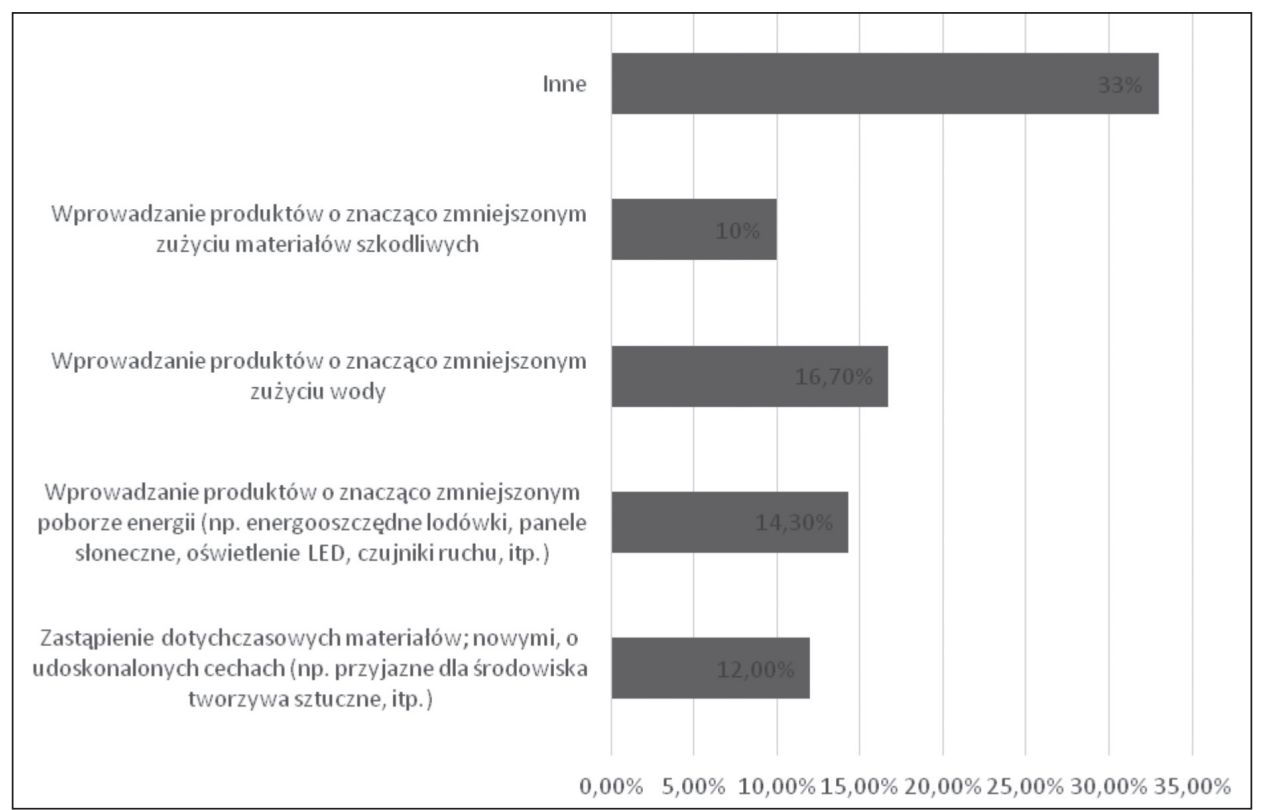

Rysunek 2. Wprowadzony ekoinnowacyjny produkt lub usługa w przedsiębiorstwie w sekcji E PKD - dostawa wody; gospodarowanie ściekami i odpadami oraz dzialalność związana z rekultywacją

Źródło: opracowanie własne na podstawie wyników badań ankietowych. 
Ponadto wprowadzono następujące innowacyjne działania:

- aktywna kontrola wycieków i dynamiczna regulacja ciśnienia w sieci wodociągowej - dzięki temu straty wody w sieci są mniejsze, a ponadto zmniejszona została liczba występujących awarii;

- elektroniczny system zarządzania stacjami uzdatniania wody, tłoczniami i przepompowniami.

Następnie zapytano przedsiębiorstwa o innowacyjny produkt lub usługę wprowadzone w ciągu poprzednich trzech lat. Przedsiębiorstwa z sekcji E Polskiej Klasyfikacji Działalności wprowadziły ekoinnowacyjne produkty i usługi, które przyniosły następujące korzyści: zmniejszenie zużycia wody $(16,7 \%)$, wprowadzenie produktów o znacząco zmniejszonym poborze energii $(14,3 \%)$, ponadto zastąpienie dotychczasowych materiałów nowymi o udoskonalonych cechach, np. przyjazne dla środowiska tworzywa (12\%), wprowadzenie produktów o znacząco zmniejszonym zużyciu materiałów szkodliwych (10\%) (rysunek 2).

W pracy zidentyfikowano również główne przyczyny wprowadzenia ekoinnowacji w przedsiębiorstwach, a także główne bariery w tym przeszkadzające: brak środków finansowych czy brak wiedzy o wpływie danego przedsiębiorstwa na środowisko naturalne.

Tabela 2. Przyczyny wprowadzenia oraz niewprowadzenia ekoinnowacji

\begin{tabular}{|l|l|}
\hline \multicolumn{1}{|c|}{ Przyczyny wprowadzenia ekoinowacji } & Przyczyny niewprowadzenia ekoinnowacji \\
\hline dbałość o środowisko & $\begin{array}{l}\text { brak takiej potrzeby - zdaniem części przedsta- } \\
\text { wicieli przedsiębiorstw }\end{array}$ \\
\hline $\begin{array}{l}\text { chęć zaspokojenia potrzeb, a także oczekiwań } \\
\text { klientów }\end{array}$ & $\begin{array}{l}\text { specyfika danego rodzaju działalności nie } \\
\text { wymaga wprowadzenia takich rozwiązań. } \\
\text { np. sektor finansowy }\end{array}$ \\
\hline chęć obniżenia kosztów & brak środków finansowych \\
\hline chęć poprawy wizerunku przedsiębiorstwa & $\begin{array}{l}\text { utrudniony dostęp do zewnętrznych środków } \\
\text { finansowania }\end{array}$ \\
\hline konieczność spełnienia wymogów prawnych & brak wiedzy na ten temat \\
\hline świadomość ekologiczna & niedostrzeganie problemów środowiskowych \\
\hline
\end{tabular}

Źródto: opracowanie własne.

W pracy skorzystano również z danych dla przedsiębiorstw z 27 Państw UE, które to dane są zgromadzone przez Instytut Gallupa ${ }^{20}$. W celu ilustracji barier mających wpływ wprowadzanie innowacji ekologicznych użyto modelu regresji

${ }^{20}$ Gallup, Attitudes of European entrepreneurs towards eco-innovation. Analytical report, Flash Eurobarometer 315, 2011. 
wielorakiej. W różnych wariantach modelu poszczególne rodzaje ekoinnowacji mierzono jako odsetek przedsiębiorstw, które wdrożyły poszczególne rodzaje ekoinnowacji w latach 2009-2010 (zmienna zależna). Zmiennymi niezależnymi były stosowane w modelach bariery mające wpływ na decyzje przedsiębiorstw, czy powinny one wprowadzić innowacje ekologiczne, czy też nie. Dla podanych obiektów naszej analizy, czyli przedsiębiorstw z 27 państw UE, wartości zmiennych niezależnych zostały obliczone jako średnie ważone, w których wagami były frakcje ankietowanych respondentów oceniających podane czynniki jako bardzo ważne i ważne. Wyróżniono ekoinnowacje produktowe, procesowe oraz organizacyjne, a ponadto zaprezentowano bariery wpływające na wprowadzanie tego typu innowacji. W analizie wykorzystano model regresji krokowej wstecznej. W wyniku obliczeń zidentyfikowano zmienne statystycznie istotne.

Tabela 3. Wyniki modelu regresji wielorakiej

\begin{tabular}{|c|c|c|c|c|c|c|}
\hline \multirow[b]{2}{*}{$\begin{array}{c}\text { Zmienne } \\
\text { niezależne }\end{array}$} & \multicolumn{6}{|c|}{ Zmienne zależne } \\
\hline & $\begin{array}{l}\text { ekoinnowa- } \\
\text { cje produk- } \\
\text { towe }\end{array}$ & $\begin{array}{c}\text { bląd } \\
\text { standar- } \\
\text { dowy }\end{array}$ & $\begin{array}{l}\text { ekoinnowa- } \\
\text { cje proce- } \\
\text { sowe }\end{array}$ & $\begin{array}{c}\text { błąd } \\
\text { standar- } \\
\text { dowy }\end{array}$ & $\begin{array}{c}\text { ekoinnowa- } \\
\text { cje organiza- } \\
\text { cyjne }\end{array}$ & $\begin{array}{c}\text { błąd } \\
\text { standar- } \\
\text { dowy }\end{array}$ \\
\hline stała & $11,18^{* *}$ & 3,75 & $22,6^{* *}$ & 4,06 & $-1,32$ & 6,24 \\
\hline $\begin{array}{l}\text { niewystarczający } \\
\text { dostęp do wiedzy } \\
\text { i nowoczesnych } \\
\text { technologii }\end{array}$ & $0,29 *$ & 0,08 & $0,36^{*}$ & 0,15 & & \\
\hline $\begin{array}{l}\text { brak partnerów } \\
\text { biznesowych }\end{array}$ & & & $-0,24 *$ & 0,1 & $-0,31 *$ & 0,14 \\
\hline $\begin{array}{l}\text { brak zewnętrzne- } \\
\text { go finansowania }\end{array}$ & & & & & $0,32 * *$ & 0,11 \\
\hline $\begin{array}{l}\text { brak wykwalifi- } \\
\text { kowanego per- } \\
\text { sonelu }\end{array}$ & & & & & $0,32 *$ & 0,15 \\
\hline R2 & 0,32 & & 0,22 & & 0,15 & \\
\hline F (p wartość) & $\begin{array}{c}12,11 \\
(<0,001)\end{array}$ & & $\begin{array}{c}3,3 \\
(<0,05)\end{array}$ & & $\begin{array}{c}4,75 \\
(<0,01)\end{array}$ & \\
\hline
\end{tabular}

${ }^{*} \mathrm{p}<0,05 * * \mathrm{p}<0,01$

Źródto: opracowanie wtasne.

Okazuje się, że na ekoinnowacje produktowe ma wpływ zmienna: „niewystarczający dostęp do wiedzy i nowoczesnych technologii”. Wbrew oczekiwaniom, zmienna ta nie stanowiła bariery dla przedsiębiorstw we wprowadzaniu 
ekoinnowacji produktowych. Inne zmienne nie były statystycznie istotne. W przypadku ekoinnowacji procesowych zmiennymi istotnymi okazały się: „,brak odpowiednich partnerów biznesowych” oraz „,ograniczony dostęp do wiedzy i nowoczesnych technologii”, ale oddziałują one w różnych kierunkach. O ile „brak odpowiednich partnerów biznesowych" nie sprzyja wprowadzeniu ekoinnowacji procesowych, zgodnie z oczekiwaniami, o tyle zmienna „ograniczony dostęp do wiedzy i nowoczesnych technologii" działa w przeciwnym kierunku, niezgodnie z intuicją. W przypadku ekoinnowacji organizacyjnych zmiennymi istotnymi okazały się: „brak odpowiednich partnerów biznesowych”, „brak finansowania zewnętrznego” oraz „brak odpowiedniego personelu”. Zmienna „brak odpowiednich partnerów biznesowych" jest statystycznie istotna i wpływa na zmniejszenie wprowadzania ekoinnowacji organizacyjnych. Pozostałe zmienne, niezgodnie z oczekiwaniami, nie stanowią bariery dla ekoinnowacji organizacyjnych.

\section{Podsumowanie}

Zaobserwowano, że badane przedsiębiorstwa dostrzegają korzyści wynikające z zastosowania ekoinnowacji - chodzi o wpływ na poprawę stanu środowiska, jak również sposób postrzegania danego przedsiębiorstwa przez udziałowców, kontrahentów czy społeczeństwo. Przynoszą one niewątpliwie efekty ekonomiczne, ekologiczne czy społeczne. Przedsiębiorstwa stosują różne rozwiązania zmniejszające zużycie materiałów, energii, wody. Najważniejszymi efektami, które wynikają z wprowadzania ekoinnowacji, są: pozytywne postrzeganie przez klientów -poprawa wizerunku przedsiębiorstwa, lepsze relacje z dostawcami. Polskie firmy mogą konkurować z tymi znajdującymi się w czołówce światowej na wielu rozdrobnionych rynkach technologii ekoinnowacyjnych, w tym w gospodarce wodnej. W przeciwieństwie do skomplikowanych technologii energetycznych, w obszarze gospodarki wodnej występują znaczne szanse na osiągnięcie sukcesu, biorąc pod uwagę zarówno wymagany potencjał, jak i wsparcie udzielane obecnie polskim innowatorom ze środków krajowych i unijnych.

Prowadzone obecnie działania proekologiczne w większości przedsiębiorstw są jednak niewystarczające i ograniczają się tylko do usuwania skutków zanieczyszczeń (rozwiązań „końca rury”), zamiast do stosowania czystszych technologii. Wydaje się, że obserwujemy obecnie dwie charakterystyczne bariery w tym zakresie. Z jednej strony niski poziom rozwoju Polski, niewystarczający, aby mógł nastąpić zasadniczy wzrost zapotrzebowania na ekoinnowacje ze strony biznesu, a z drugiej strony nie przeznacza się na te działania istotnych środków, gdyż wątpliwe jest, aby były one właściwie wykorzystane. 


\section{Bibliografia}

Abdala M.A., Governance of competitive transmission investment in weak institutional systems, „Energy Econ” 2008, vol. 30, no. 4.

Andersen M., Eco-innovation - Towards a taxonomy and a theory, 25th Celebration DRUID Conference 2008 on Entrepreneurship and Innovation - Organizations, Institutions, Systems and Regions, Copenhagen, Denmark.

Arundel A., Kemp R., Measuring eco-innovation, United Nations University - Maastricht Economic and Social Research and Training Centre on Innovation and Technology, UNU-MERIT Working Papers, UNU, Maastricht 2009.

Beise M., Rennings K., Lead Markets and Regulation: a Framework for Analyzing the International Diffusion of Environmental Innovations, „Ecological Economics” 2005, vol. 52, no. 1.

Białoń L., Zarządzanie działalnością innowacyjną, Placet, Warszawa 2010.

Bukowski M., Szpor A., Śniegocki A., Drzemiący tygrys, spętany orzet: Dylematy polskiej debaty o polityce innowacyjnej, Instytut Badań Strukturalnych, Warszawa 2012.

Carrillo-Hermosilla J., del Rio Gonzalez P., Könnölä T., Eco-Innovation. When Sustainability and Competitiveness Shake Hands, Palgrave Macmillan, New York 2009.

De Marchi V., Environmental innovation and R\&D cooperation: Empirical evidence from Spanish manufacturing firms, ,Research Policy” 2012, vol. 41, no. 3.

Fussler C., James T., Driving Eco-Innovation: a breakthrough discipline for innovation and sustainability, Pitman Publishing, London 1996.

Galia F., LeGros D., Complementarities between obstacles to innovation: evidence from France, „Research Policy” 2004, vol. 33.

Gallup, Attitudes of European entrepreneurs towards eco-innovation. Analytical report, Flash Eurobarometer 315, 2011.

GUS, Działalność innowacyjna przedsiębiorstw 2006-2009, 2009, www.stat.gov.pl/cps/rde/xbcr/ gus/nts_dzialanosc_innowacyjna_2006-2009.pdf(dostęp: 1.06.2016).

Hadjimanolis A., Barriers to innovation for SMEs in a small less developed country, ,Technovation" 1999, nr 19.

Harutyunyan N., Metering drinking water in Armenia: The process and impacts, ,Journal of Sustainable Cities and Society" 2014, vol. 14.

Hemmelskamp J., Umweltpolitik und technischer Fortschritt. Eine theoretische und empirische Untersuchung der Determinanten von Umweltinnovationen, Physica, Heidelberg 1999.

Hewitt-Dundas N., Resource and capability constraints to innovation in small and large plants, „Small Business Economics” 2006, vol. 26, no. 3.

Jakobsen S, Clausen T., Comparing the innovation process in environmental and non-environmental firms: A look at barriers to innovation. DRUID Society Conference, CBS, Copenhagen 2014.

Janasz W., Innowacje i ich miejsce w tworzeniu wartości przedsiębiorstwa, [w:] W. Janasz (red.), Innowacje $w$ działalności przedsiębiorstw $w$ integracji z UE, Difin, Warszawa 2005.

Jones E., Harrison D., McLaren J., Managing creative eco-innovation, structuring outputs from eco-innovation projects. ,The Journal of Sustainable Product Design” 2001, nr 1.

Kassenberg A., Kassenberg P., Ecoinnovation in Poland, Ecoinnovation Observatory, Country profile 2011.

Kassenberg A., Śniegocki A., Rola (eko)innowacji w niskoemisyjnej transformacji, Instytut na Rzecz Ekorozwoju, Warszawa 2011.

Kemp A., Pearson P., Measuring eco-innovation. Final report of MEI project for DG Research of the European Commission, MEI, Brussels 2007. 
Klemmer P., Lehr U., Löbbe K., Umweltinnovationen. Anreize und Hemmnisse, Analytica Verlag, Berlin 1999.

Macharzina K., Unternehmensführung, Gabler, Wiesbaden 1999.

Marid-Guijarro A., Garcia D., Van Auken H., Barriers to Innovationamong Spanish Manufacturing SME, „Journal of Small Business Management” 2009, vol. 47, no. 4.

OECD, Oslo manual, the measurement of scientific and technological activities proposed guidelines for collecting and interpreting technological innovation data, 2005, www.oecd.org (dostęp: 1.06.2016).

Ottman J., The New Rules of Green Marketing: Strategies, Tools, and Inspiration for Sustainable Branding, Greenleaf Publishing, Sheffield 2011.

Parvan S.-V., Statistics in focus, „Science and Technology” 2007, nr 117, http://epp.eurostat.ec.europa.eu/cache/ITY_OFFPUB/KS-SF-07-113/EN/KS-SF-07-113-EN.PDF (dostęp: 1.06.2016).

Reid A., Miedzinski M., ECO-INNOVATION. Final Report for Sectoral Innovation Watch, Technopolis Group, Brighton 2008.

Rennings K., Redefining innovation - eco-innovation research and the contribution from ecological economics, „Ecological Economics” 2000, vol. 32.

Schiederig T., Tietze F., Herstatt C., Green innovation in technology and innovation management - an exploratory literature review, ,R\&D Management” 2012, vol. 42, no. 2.

Schmidt-Bleek F., Eco-innovation, final report for sectoral innovation watch, www.technopolis-group.com/resources/downloads/661_report_final.pdf (dostęp: 1.06.2016).

Steward F., Opponent note: ecoinnovation-enviromental benefits [w:] Economic growth and job creation, 2006.

Woźniak L., Trinks R., Bącal W., Ekoinnowacje - nowy paradygmat, odmienna gospodarka, proekologiczna świadomość przedsiębiorców, [w:] A. Kaleta, K. Moszkowicz, L. Woźniak, Przedsiębiorczość i innowacyjność matych i średnich przedsiębiorstw - wyzwania wspótczesności, Wydawnictwo Akademii Ekonomicznej we Wrocławiu, Wrocław 2004.

Ziółkowski B., Znaczenie ekoinnowacji dla rozwoju przedsiębiorstw, [w:] A. Graczyk (red.), Zrównoważony rozwój $w$ teorii ekonomii i w praktyce, Wydawnictwo Akademii Ekonomicznej we Wrocławiu, Wrocław 2007, Prace Naukowe AE, nr 1190.

\section{Streszczenie}

W artykule omówiona jest definicja i podział ekoinnowacji oraz pokazany przykład ekoinnowacji w gospodarce wodnej w Polsce. Jest to pojęcie nowe i trudne do zdefiniowania, wciąż trwają dyskusje, w jakim stopniu definicja innowacji może być zastosowana do ekoinnowacji. Skutkiem proekologicznych działań jest nie tylko poprawa jakości środowiska, ale równoczesne obniżenie kosztów funkcjonowania przedsiębiorstwa. Na podstawie danych uzyskanych z badań ankietowych oceniono rodzaj wpływu różnych barier na wprowadzenie ekoinnowacji produktowych, procesowych i organizacyjnych.

Słowa kluczowe: ekoinnowacje organizacyjne, produktowe, procesowe, przedsiębiorstwo 